\title{
Toward a Framework for 'Āina-Based Pedagogies: A Hawai'i Approach to Indigenous Land-Based Education
}

\author{
Summer P. Maunakea \\ University of Hawai'i at Mānoa
}

\begin{abstract}
'Āina-based initiatives are not only proliferating in Hawai ' $i$ communities, but also in academic institutions where interest in place-based education, sustainability education, and STEM has increased. In an effort to uphold the integrity of 'aina and promotes its integration into PreK-20 learning settings, this article describes characteristics of 'äina-based pedagogies as a Hawai' $i$ approach to Indigenous land-based education. This research presents ancestral Hawaiian principles of 'aina-based pedagogies, along with the learning environments that 'aina-based education occurs in, common instructional approaches, fields of study, and purposes of application. Findings from this study ground 'aina-based learning in a Kanaka 'Öiwi perspective and may assist others in designing 'aina-based learning experiences, strengthening their educational initiatives, and evaluating their programmatic outcomes.
\end{abstract}

Keywords: 'Aina-based education, Indigenous land-based education, place-based education, 'Ōiwi agency

\section{INTRODUCTION}

As Hawaiians, we have a powerful kinship to the 'aina. This familial connection continually reminds us of our kuleana (responsibility) to each other and the planet. The 'aina is as much a theater for learning as it is a repository of life. 'Äina can be a teacher, a classroom, and a living laboratory for education in next-century skills, sustainability, and self-determination. (Ledward, 2013, p. 35)

The term 'aina ${ }^{1}$-based education has only recently emerged in the fields of education and educational research, whereas the values and practices that undergird 'aina-based education have been exercised by generations of Kānaka 'Ōiwi'. 'Āina-based pedagogies include dynamic and interdisciplinary processes of learning and teaching that hail from the natural landscapes and oceanscapes of Hawai' $i$ 's environment. These processes, which emphasize an interconnected relationship between Kānaka 'Ōiwi and the 'āina, draw upon place-specific intergenerational knowledge systems, language, and customary practices to frame curricula for all learners. In Ledward's (2013) study of 'aina-based education in the dryland forest of $\mathrm{Ka}$ ' 'ūpūlehu on the west side of Hawai' $i$ Island, he describes students' learning alongside community leaders and scientists, and "coming to appreciate their 'äina as a rich source of knowledge and a launch-pad for future career aspirations" (Ledward, 2013, p. 38). He suggests that 'āina-based learning can guide future educational programs and initiatives 
- through the sharpening of people's critical thinking and problem-solving skills through firsthand experience with the 'äina-linking newly-acquired knowledge with enduring cultural principles,

- by understanding long-term consequences of people's actions, as well as their dependence on available resources, and

- as sites for self-determination through developing a kinship and kuleana to Hawai' $i$ which may lead to civic engagement and political action (Ledward, 2013).

'Āina-based initiatives, then, are emerging as catalysts for transformative praxis-empowering Kānaka 'Ōiwi to enact agency (G. Smith, 1997; 2005).

In 2014, Decolonization: Indigeneity, Education \& Society published a special issue on the topic of land-based education. The editors state, "If colonization is fundamentally about dispossessing Indigenous peoples from land, decolonization must involve forms of education that reconnect Indigenous peoples to land and the social relations, knowledges and languages that arise from the land" (Wildcat et al., 2014, p. i). Reconnecting Indigenous peoples to the land, social relations, knowledges and languages can be achieved through 'aina-based education. However, in my review of the literature, I have not found a comprehensive framework that offers detailed pedagogy for 'āina-based learning. This missing piece presents an opportunity for Kānaka 'Ōiwi to define what 'āina-based education entails and the desired outcomes in the context in which it occurs. This paper addresses the following questions in order to articulate characteristics of 'āina-based education:

- What are the foundational ancestral principles of 'āina-based pedagogies?

- How are the ancestral principles of 'āina-based pedagogies given meaning through 'āina-based education?

\section{THEORETICAL FRAMEWORK}

The traditional principles of traditional knowledge...remain fixed and provide the framework within which new experiences and situations are understood and given meaning. As such, these principles are the means by which cultural knowledge becomes remade and given meaning in our time. (Carl Urion, as cited in Stewart-Harawira, 2005, p. 155)

A review of the relevant literature reveals ten principles ${ }^{3}$ of traditional knowledge that undergird 'āinabased pedagogies. These principles are critical factors in 'āina-based programming because they strengthen familial and reciprocal relationships between Kānaka 'Ōiwi and the 'āina. By identifying these principles, Kānaka 'Ōiwi are able to frame their cultural practices and teachings within the context of ancestral values while at the same time bringing the relevance of place-specific cultural knowledges and practices to the present day. From this body of information, it is clear that each principle is inextricably linked to a number of others, thereby illustrating the complexities involved in reclaiming the teachings of our kuppuna to share it with succeeding generations (Young, 1998).

\section{DATA SOURCES AND METHOD}

The multifaceted nature of 'āina-based learning is documented throughout the disciplines of education, public health, natural resource management, agroecology, Hawaiian studies, language studies, anthropology, geography, psychology, and political science, to name a few. To illustrate this multifaceted nature, various academic research articles and book chapters in the fields mentioned above have been gathered from online databases using the following search/key terms: "aaina-based -learning, -education, program", "land-based education", "biocultural restoration", "indigenous education", and "culture-based education". A spreadsheet ${ }^{4}$ was created to categorize search results according to location and type of program sites, support organizations, and type of research, which include published research and evaluation studies, theses and dissertations, and descriptive studies (see Appendix). The literature in the field of 'âina- 
based education is growing - but programmatic structure, pedagogical approaches, and program findings are not always reported in written form or made available on online sources. Oral presentations by many cultural practitioners and educators who are leaders in their communities are often shared at conferences and community presentations. Therefore, attended presentations and presentation findings are included as a category to affirm the knowledge generated by community-engaged research.

Literary sources as well as conference and community presentation notes were read and coded to build a collective understanding of how researchers and community leaders were describing their 'āina-based efforts. The following themes surfaced from the data: traditional/ancestral principles, diverse learning environments, the purposes of use in diverse fields, and instructional strategies used in 'āina-based education.

\section{FINDINGS: DEFINING PEDAGOGIES OF ‘ĀINA-BASED EDUCATION}

The term pedagogy refers to the theory and practice of education. Pedagogy includes the context, relationships, purpose, content, instructional strategies, and impact related to the learning setting, and is generally used in its singular form. Although there are similarities in 'aina-based education across the Hawaiian islands such as emphasis on place-based knowledge and sustainability practices to cultivate healthy people and place, learning approaches may differ significantly depending on the context and the environment. Therefore, the term "pedagogies" is used to describe the diverse learning contexts that 'āinabased education occurs in, the fields in which it is applied, and the instructional approaches used to guide learners in 'āina-based relationships. The ancestral principles, learning environments, the purposes of use in diverse fields, and instructional strategies used in 'āina-based education follows.

\section{Ancestral Principles}

Each principle, as presented here, includes descriptions from a range of knowledge holders and how it is enacted through place-specific 'āina-based efforts.

- Mo'okū'auhau—genealogy. The sharing of mo'okū'auhau through reciting mele ko'ihonua, cosmogonic genealogies, is a common practice amongst 'āina-based programs to acknowledge and connect with the mana of their places.

- 'Ōlelo Hawai' $\mathrm{i}$-Hawaiian language. 'Ōlelo Hawai'i contains the stories and the shared identity of its people (Warner, 1999) and it connects learners to the history and essence of a particular 'āina (Oliveira, 2014, 2017; Veincent, 2016).

- Ho'omana-power, spirituality, reverence, and the ability for Kānaka 'Ōiwi to "open the mutual flow of mana within a relationship" (Goodyear-Ka'ōpua, 2013, p. 208). Inherited and acquired mana can be drawn on in 'āina-based education to develop innovative socio-cultural structures that improve the well-being of Kanaka 'Ōiwi communities and rebuild community understandings of abundance (Enos, 2015; Maunakea-Forth \& Abbott, 2015).

- 'Āina momona - "productive, healthy, and resilient lands and oceans including the intimate reciprocal relationships our ancestors had with 'äina..." (Morishige et al., 2018, p. 15). Momona means fat, fertile, or rich as in soil. 'Āina momona is an important aspect of 'āina-based education because it provides a foundation to measure the health of 'āina, kānaka, and the impact of 'äina-based programming.

- Kuleana - notions of responsibility, roles, and obligations. Kuleana is an important aspect of 'aina-based education because it is through the exercise of kuleana, that people grow a relationship to their place (Vaughan, 2018).

- Aloha 'aina - “....an unswerving dedication to the health of the natural world and a staunch commitment to political autonomy" (Goodyear-Ka'ōpua, 2013, p. 32). Aloha "āina is an important aspect to 'āina-based education because it simultaneously expresses a commitment to the health of the 'âina as well as the struggle for Kānaka 'Ōiwi to regain sovereignty over their governing systems. 
- Mauli ola - a concept of Hawaiian well-being that embraces physical and spiritual facets of holistic health. Mauli ola is an important aspect of 'aina-based education because interdependent person-environment relationships are necessary for Kanaka 'Ōiwi well-being (Vaughan, 2018).

- 'Ike kupuna - knowledge of elders and ancestors. 'Ike kupuna is an important aspect of 'āinabased education because inherent in intergenerational knowledge systems are unique characteristics, patterns, and relationships of each place.

- Mo'olelo - stories, traditions, literature, and historical accounts. Mo'olelo is an important aspect of 'aina-based education because the transmission of traditions and stories is essential to Kanaka 'Ōiwi identity and connection to place (Oliveira \& Wright, 2016).

- 'Ohana-family or community; often translated as "offshoots of the family stalk" in reference to the 'ohā or offshoots of the kalo plant (Handy \& Pukui; 1972). 'Ohana is an important aspect of 'àina-based education because it is a means to rebuild self-sufficient community-based food systems.

\section{Learning Environments}

The learning environments in which 'āina-based education occurs are cultural kīpuka where Hawaiian culture can be regenerated and revitalized in contemporary settings (McGregor, 2006). 'Āina-based education has been observed across diverse learning environments which include, but are not limited to

- natural ecosystems - native forests and ocean/reef systems,

- regenerative community food systems ${ }^{5}$-lo'i kalo, loko i'a, 'āina malo'o: dryland and rain-fed field systems, organic farms, māla'ai, community gardens, medicine gardens, food forests, and school gardens,

- home and community life — wahi pana, home gardens, public health centers, and community non-profit organizations, and

- academic institutions-Hawai'i's private, public, and charter schools; post-secondary institutions such as the University of Hawai'i System; and private colleges and universities.

\section{Fields of Study and Purposes of Application}

The diversity of settings in which 'āina-based learning occurs is paralleled by the variety of fields in which it is applied and the purposes for which it is of benefit. These include

- Hawaiian language revitalization (Oliveira, 2017),

- sustainability and STEM education (Hawai'i Leadership Forum, 2019),

- Kanaka 'Ōiwi and Indigenous leadership (Ah Nee-Benham, 2016; Aldana, 2019; Beamer, 2013; Cajete, 2015; Osorio, J. K., \& Osorio J., 2016; Oliveira, 2017), native plant restoration and invasive species control (Sato \& Cavalieri, 2019),

- food sovereignty (Enos, 2015; Goodyear-Ka'ōpua, 2013; Meyer, 2014; Youth Food Sovereignty Congress, 2018),

- biocultural restoration (Kurashima, Jeremiah, \& Ticktin, 2017; Lincoln et al., 2018; Morishige et al., 2018),

- $\quad$ workforce development (Maunakea-Forth \& Abbott, 2015),

- epigenetics, economics, and public health (A. Maunakea \& Juarez, 2018; Fujita, Braun, \& Hughes, 2004; Oshiro, 2019),

- intergenerational education (Nāone, 2008, S. Maunakea, 2014), and

- cultural literacy (ho'omanawanui, 2008).

\section{Instructional Approaches}

Instructional approaches of 'āina-based learning are guided by 'Ōiwi processes of knowing and doing such as

- ceremonial protocol to remind learners of their pilina and accountability to place, genealogy, and akua (Goodyear-Ka‘ōpua, 2013), 
- kilo-keen place-based observation over an extended period of time "to build a collective and intimate understanding of biocultural landscapes and seascapes" (Morishige et al., 2018, p. 9),

- ma ka hana ka 'ike-learning through doing (Lincoln et al., 2018; Meyer, 2014),

- laulima - many hands working together to start and complete tasks. Laulima broadly includes the organizations that advocate for and help build capacity of 'āina sites to mālama their own biocultural resources (Kua'āina Ulu 'Auamo, 2019), and

- 'Ōiwi agency — blending the use of 'Ōiwi and Western frameworks to cultivate abundance for current and future generations (Beamer, 2014; Kealiikanakaoleohaililani \& Giardina, 2016).

\section{SIGNIFICANCE: THE NEED TO CLAIM KANAKA 'ŌIWI PROCESSES OF TEACHING}

Kanaka 'Ōiwi and Indigenous scholars assert the need to claim Indigenous identities, research, language, schooling, and systems to make positive differences in Indigenous lives (ho'omanawanui, 2008; Kana'iaupuni, Ledward, \& Malone; 2017; Maaka, 2004; L. Smith; 2012). 'Āina-based initiatives are not only proliferating in Hawai' $i$ communities, but also in academic institutions where interest in place-based and project-based education; sustainability education; social-emotional learning; science, technology, engineering, and mathematics education (STEM); farm to school; and Nā Hopena A'o policy has increased (Hawai'i State Department of Education, 2012, 2017; Hawai'i Leadership Forum, 2019). The research findings presented in this paper offer components toward a conceptual framework for community leaders, scholars, educators, and cultural practitioners to engage in discussion about the intricacies of 'aina-based education. Such discussions may help communities evaluate the impact of their programming and lead to further development of their 'āina-based initiatives.

\section{ENDNOTES}

1. 'Āina encompasses land, earth - that which feeds and that which signifies a sense of homeland relations between people and the land. 'Ōlelo Hawai' $i$, Hawaiian language, words and phrases are used throughout the text. If English explanations for Hawaiian words are needed, see: Pukui M. K., \& Elbert S. H. (1986). Hawaiian dictionary: Hawaiian-English, English-Hawaiian (revised and enlarged ed.), Honolulu, HI: University of Hawaii Press. Alternatively, search www.wehewehe.org. Hawaiian words and phrases are italicized and/or followed by an English translation only when quoted.

2. Throughout the text, the following terms are used to describe descendants of the native people of ka pae 'aina Hawai'i: Kānaka 'Ōiwi, Kānaka (plural), Kanaka (singular), and Hawaiian. Kanaka, 'Ōiwi, and Hawaiian are also used as adjectives. When written kanaka (singular) or kānaka (pural), this refers to a person and all of humanity, respectively.

3. Mo'okū'auhau, 'ōlelo Hawai'i, ho'omana, 'āina momona, kuleana, aloha 'āina, mauli ola, 'ike kupuna, mo'olelo, and "ohana are the ten "ancestral principles" selected from the knowledge base. They are called "ancestral principles" in reference to the values and practices that have been exercised by generations of Kānaka 'Ōiwi. Furthermore, the 'āina-based programs discussed in this article have come to recognize these values and practices as guiding principles of their work. With that being said, it should be emphasized that 'äina-based organizations must consider the values and practices most aligned to their place and context whether they are discussed in this article as an "ancestral principle" or not.

4. The spreadsheet was generated at the time of the study utilizing literature sources and prior knowledge of existing organizations. It is not comprehensive or inclusive of all 'āina-based programs, reports, or support organizations across ka pae 'āina 'o Hawai'i. Email smauna@hawaii.edu for corrections or additions, mahalo.

5. According to the Rodale Institute (2014, p. 7), "Regenerative organic agriculture improves the resources it uses, rather than destroying or depleting them. It is a holistic systems approach to agriculture that encourages continual on-farm innovation for environmental, social, economic and spiritual well-being." For the purpose of this article the term regenerative community food systems is used to describe Hawai'i's food systems that align with regenerative organic agricultural practices. These include 'Ōiwi agricultural and aquacultural structures such as lo'i kalo, loko i'a, and 'āina malo'o field systems that holistically nourish Hawai'i's communities in the present day. 


\section{REFERENCES}

Ah Nee-Benham, M.K.P. (2016). Making and mending net: The hana lawelawe of higher education in Hawai'i. Hülili: Multidisciplinary Research on Hawaiian Well-Being, 10, 281-296.

Aikau, H.K., \& Camvel, D.A.K. (2016). Cultural traditions and food: Kānaka Maoli and the production of poi in the He'e'ia wetland. Food, Culture \& Society, 19(3), 539-561.

Aldana, E.N. (2019). Growing leadership at Ho 'oulu 'Aina: Matching up gifts and kuleana in order to heal land, people, and community (doctoral dissertation). University of Hawai'i at Mānoa, Hawai'i.

Beamer, K. (2013). 'Ōiwi leadership and 'āina. In J.K. Osorio (Ed.), I ulu i ka 'äina = land (pp. 55-61). Honolulu, HI: University of Hawai'i Press.

Beamer, K. (2014). No mākou ka mana: Liberating the nation. Honolulu, HI: Kamehameha Publishing.

Cajete, G.A. (2015). Indigenous community: Rekindling the teachings of the seventh fire. St. Paul, MN: Living Justice Press.

Enos, K. (2015, May). Using ancestral frameworks to create contemporary abundance. Paper presented at the Indigenous Education Symposium, Honolulu Convention Center, Honolulu, Hawai'i.

Fujita, R., Braun, K.L., \& Hughes, C.K. (2004). The traditional Hawaiian diet: A review of the literature. Pacific Health Dialog, 11(2), 250-259.

Goodyear-Ka'opua, N. (2013). The seeds we planted: Portraits of a Native Hawaiian charter school. Minneapolis, MN: University of Minnesota Press.

Handy, E.S.C., \& Pukui, M.K. (1972). The Polynesian family system in Ka- 'u Hawai ' $i$ (2nd ed.). Rutland, VT: Charles E. Tuttle.

Hawai'i Leadership Forum. (2019). 'Āina-based education systems map: Mapping what enables and inhibits 'äina-based education in Hawai' $i$. Retrieved February 28, 2019, from https://kumu.io/hlf/aina-based-education

Hawai'i State Department of Education. (2017). Hawai' $i$ State Department of Education \& Board of Education strategic plan 2017-2020 [PDF file]. Retrieved February 20, 2019, from http://www.hawaiipublicschools.org/DOE\%20Forms/Advancing\%20Education/SP2017- 20.pdf

Hawai'i State Department of Education. (2012). Strategic plan 2011-2018 [PDF file]. Retrieved February 20, 2019, from http://www.hawaiipublicschools.org/DOE\%20Forms/Advancing $\% 20$ Education/StrategicPlan.pdf

ho'omanawanui, K. (2008). 'Ike 'āina: Native Hawaiian culturally based indigenous literacy. Hūlili: Multidisciplinary Research on Hawaiian Well-Being, 5, 203-244.

Kana'iaupuni, S.M., Ledward, B., \& Malone, N. (2017). Mohala i ka wai: Cultural advantage as a framework for indigenous culture-based education and student outcomes. American Educational Research Journal, 54(1_suppl), 311s-334s. Retrieved March 1, 2019, from https://www.ksbe.edu/assets/pdfs/Mohala_i_ka_wai_Cultural_Advantage.pdf

Kealiikanakaoleohaililani, K., \& Giardina, C.P. (2016). Embracing the sacred: An indigenous framework for tomorrow's sustainability science. Sustainability Science, 11(1), 57-67.

Kua'āina Ulu 'Auamo. (2019). About KUA. Retrieved February 28, 2019, from http://kuahawaii.org/about/

Kurashima, N., Jeremiah, J., \& Ticktin, T. (2017). I ka wā ma mua: The value of a historical ecology approach to ecological restoration in Hawai'i. Pacific Science, 71(4), 437-456.

Ledward, B. (2013). 'Āina-based learning is new old wisdom at work. Hülili: Multidisciplinary Research on Hawaiian Well-Being, 9, 35-48.

Lincoln, N., Rossen, J., Vitousek, P., Kahoonei, J., Shapiro, D., Kalawe, K., . . Meheula, K. (2018). Restoration of 'āina malo'o on Hawai' $i$ island: Expanding biocultural relationships. Sustainability, 10(11), 3985.

Maaka, M.J. (2004). E kua takoto te mānuka tūtahi: Indigenous decolonization, self-determination, and education. Educational Perspectives, 37(1), 3-13. 
Maunakea, A.K., \& Juarez, R. (2018, December). Enabling sustainable health in our communities. Community presentation at Feeding Hawai'i: Who \& How, Ka Waiwai, Community meeting, Mō'ili'ili, Hawai'i.

Maunakea, S.P. (2014) Community learning exchange: 'Ohana series program evaluation findings (unpublished report). Kamehameha Schools, Hawai'i.

Maunakea-Forth, K., \& Abbott, M. (2015, May). MA 'O: A community endeavor to restore our food \& education sovereignty. Paper presented at the Indigenous Education Symposium, Honolulu Convention Center, Honolulu, Hawai'i.

McGregor, D.P. (2006). Nā kua 'äina: Living Hawaiian culture. Honolulu, HI: University of Hawai'i Press.

Meyer, M.A. (2014). Hoea ea: Land education and food sovereignty in Hawaii. Environmental Education Research, 20(1), 98-101. Retrieved February 28, 2019, from https://www.tandfonline.com/doi/abs/10.1080/13504622.2013.852656

Morishige, K., Andrade, P., Pascua, P., Steward. K., Cadiz, E., Kapono, L., \& Chong, U. (2018). Nā kilo 'āina: Visions of biocultural restoration through indigenous relationships between people and place. Sustainability, 10(10), 3368.

Nāone, C.K. (2008). The Pilina of Kanaka and 'āina: Place, language and community as sites of reclamation for indigenous education the Hawaiian case (doctoral dissertation). Retrieved September 20, 2018, from http://scholarspace.manoa.hawaii.edu/ handle/10125/20846

Oliveira, K-A.R.K.N. (2014). Ancestral places: Understanding Kanaka geographies. Corvallis, OR: Oregon State University Press.

Oliveira, K-A.R.K.N., \& Wright, E.K. (Eds.). (2016). Kanaka 'Ōiwi methodologies: Mo 'olelo and metaphor. Honolulu, HI: University of Hawai'i Press.

Oliveira, K-A.R.K.N. (2017). Aloha 'āina-placed ho'omoana 'ōlelo Hawai'i: A path to language revitalization. In E. McKinley \& L. Smith (Eds.), Handbook of Indigenous Education (reference work entry, pp. 1-18). Singapore: Springer. Retrieved June 21, 2019, from https://link.springer.com/referenceworkentry/10.1007\%2F978-981-10-1839-8_15-1

Oshiro, J. (2019, February 20). UH study of MA'O farms shows interns reaping health benefits. Honolulu Star Advertiser, pp. F6-F7.

Osorio, J.K., \& Osorio, J. (2016). Two perspectives on political narrative in one activist family. Hūlili: Multidisciplinary Research on Hawaiian Well-Being, 10, 185-201.

Pukui, M.K., \& Elbert, S.H. (1986). Hawaiian dictionary: Hawaiian-English, English-Hawaiian (revised and enlarged ed.). Honolulu, HI: University of Hawaii Press.

Rodale Institute. (2014). Regenerative organic agriculture and climate change: A down-to-earth solution to global warming [PDF file]. Retrieved May 2, 2019, from https://rodaleinstitute.org/wpcontent/uploads/rodale-white-paper.pdf

Sato, P., \& Cavalieri, M. (2019, January). Mālama Learning Center. Paper presented at 'Aha 'Āina Aloha, University of Hawai' $\mathrm{i}$-West O'ahu, Kapolei, Hawai' $\mathrm{i}$.

Smith, G.H. (1997). The development of Kaupapa Maori: Theory and praxis (doctoral dissertation). University of Auckland, Aotearoa/New Zealand.

Smith, G.H. (2005). Beyond political literacy: From conscientization to transformative praxis. Counterpoints, 275, 29-42. Retrieved May 1, 2019, from http://www.jstor.org/stable/ 42978775

Smith, L.T. (2012). Decolonizing methodologies: Research and indigenous peoples (2nd ed.). London: Zed Books.

Stewart-Harawira, M. (2005). Cultural studies, indigenous knowledge and pedagogies of hope. Policy Futures in Education, 3(2), 153-163. Retrieved August 15, 2015, from https://journals.sagepub.com/doi/pdf/10.2304/pfie.2005.3.2.4

Vaughan, M.B. (2018). Kaiāulu: Gathering tides. Corvallis, OR: Oregon State University Press.

Veincent, L. (2016). Mauli Keaukaha: Cultural knowledge and education in the Keaukaha community (doctoral dissertation). University of Hawaii at Mānoa, Hawai‘i. 
Warner, S.L.N. (1999). "Kuleana": The right, responsibility, and authority of indigenous peoples to speak and make decisions for themselves in language and cultural revitalization. Anthropology \& Education Quarterly, 30(1), 68-93. Retrieved June 16, 2019, from https://www.jstor.org/stable/3195982

Wildcat, M., McDonald, M., Irlbacher-Fox, S., \& Coulthard, G. (2014). Learning from the land: Indigenous land based pedagogy and decolonization. Decolonization: Indigeneity, Education and Society, 3(3), i-xv.

Young, K.G.T. (1998). Rethinking the Native Hawaiian past. New York, NY: Routledge Publishing.

Youth Food Sovereignty Congress. (2018). Ho 'òla 'äina youth food sovereignty statement (unpublished report). MA`O Organic Farms, Hawai'i. 


\section{APPENDIX}

\section{‘Āina-Based Programs Spreadsheet}

\begin{tabular}{|c|c|c|c|c|}
\hline 'Ãina-based Component & Organization Name/School & Host Organization & Setting & $\begin{array}{l}\text { Literature/ } \\
\text { Conference Presentations }\end{array}$ \\
\hline Assessment/Evaluation & Waipã - Mehana Blaich Masters Thesis & Waipã Foundation & Ahupua'a & Blaich (2003) \\
\hline Assessment/Evaluation & Waipã - Molly Mamaril Masters Thesis & Waipã Foundation & Ahupua'a & Mamaril (2015) \\
\hline Educational Program & First Nation Futures Programs & Kamehameha Schools & Multiple & Beamer (2013) \\
\hline Educational Program & Ho'olauna Programs & Kamehameha Schools & Lo'i Kalo/Loko l'a & ho'omanawanui (2008) \\
\hline Educational Program & Ho'omāka'ika'i Programs & Kamehameha Schools & Multiple & \\
\hline Educational Program & “ÃINA In Schools & Kōkua Hawai'i Foundation & School Gardens & \\
\hline Educational Program & Mauiakama & UHMCC/UHM & Lo'i Kalo/Mulitple & Oliveira (2017) \\
\hline Educational Program & Nã Kilo ‘Āina & Nã Kilo 'Āina & Multiple & Morishige et al (2017) \\
\hline Educational Program & Noho Papa & Edith Kanaka'ole Foundation & Multiple & \\
\hline Educational Program & Mālama Learning Center & Mălama Learning Center & Multiple & Sato \& Cavalieri (2019) \\
\hline Support Organization & Castle Foundation & Castle Foundation & - & \\
\hline Support Organization & Consuelo Foundation & Consuelo Foundation & - & \\
\hline Support Organization & Hau'oli Mau Loa Foundation & Hau'oli Mau Loa Foundation & - & \\
\hline Support Organization & Kua'âina Ulu 'Auamo & Kua'āina Ulu 'Auamo & - & \\
\hline Support Organization & Kohala Center & Kohala Center & - & \\
\hline Support Organization & Kōkua Hawai'i Foundation & Kōkua Hawai'i Foundation & - & \\
\hline Support Organization & KUPU & KUPU & - & \\
\hline Support Organization & Mālama 'Āina Foundation & Mālama 'Āina Foundation & - & \\
\hline Hui/Network & Hawai'i Farm to School Hui & Hawaii Public Health Institute & - & \\
\hline Hui/Network & ‘Āina Ulu & Kamehameha Schools & - & Hannahs (2014) \\
\hline Hui/Network & Ko'olauloa 'Āina-based Education Hui & Castle Foundation; various & - & \\
\hline Other Research & W. K. Lee's Masters Thesis & UH Mãnoa & - & Lee (2014) \\
\hline Other Research & ‘Āina Ulu Report (2011) & Kamehameha Schools & - & \\
\hline Other Research & 'Āina-based Education Systems Map & $\begin{array}{l}\text { Hau'oli Mau Loa/KS/Consuelo/Hawaii } \\
\text { Leadership Forum }\end{array}$ & - & Hawai'i Leadership Forum (2019) \\
\hline Program Site & He Moku He Wa'a, He Wa'a He Moku Farm & Kãnehûnāmoku Voyaging Academy & Lo'i kalo/'Āina malo'o & Goodyear-Ka'ōpua (2013) \\
\hline Program Site & Ho'óulu'ulu Kahalu'u & Ho'o'ulúulu Kahalu'u & 'Āina malo'o & Lincoln et al. (2018) \\
\hline Program Site & Ho'okua'āina & Ho'okua'āina & Loi kalo & \\
\hline Program Site & Ho'oulu 'Āina & Kōkua Kalihi Valley & 'Āina malo'o, native forest & Mahi (2013); Baker (2018); Aldana (2018) \\
\hline Program Site & Hui Kū Maoli Ola & Hui Kũ Maoli Ola & Native plants & Barboza (2013) \\
\hline Program Site & Hui Mālama i ke Ala 'Ôlili (huiMAU) & Hui Mălama i ke Ala 'Ōlili (huiMAU) & 'Āina malo'o & Peralto (2018); Lincoln et al. (2018) \\
\hline Program Site & Ka Honua Momona & Ka Honua Momona & Loko l'a & \\
\hline Program Site & Ka Papa Lo'i 'o Punalu'u & Kamehameha Schools/UH Mãnoa & Loi kalo & \\
\hline Program Site & Ka'ala Farm & Ka'ala Farm & Lo'i kalo & \\
\hline Program Site & Kahana & Kahana & Loi kalo & \\
\hline Program Site & Kăko'o ‘Ōiwi & Kāko‘o 'Ōiwi & Lo'i Kalo/'Ãina malo'o & Aikau \& Camvel (2016) \\
\hline Program Site & Kãnehūnāmoku Voyaging Academy & Kãnehûnāmoku Voyaging Academy & Wa'a/Lo'i kalo & Goodyear-Ka'ōpua (2013) \\
\hline Program Site & Keiki and Plow & Keiki and Plow/KS & 'Āina malo'o & \\
\hline Program Site & Keiki o ka 'Āina & Keiki o ka 'Ãina & Māla'ai/Lo'i kalo & \\
\hline Program Site & Kưu Home Kulāiwi & Ku'u Home Kulāiwi & Lo'i Kalo & \\
\hline Program Site & Kumano I Ke Ala & Kumano I Ke Ala & Lo'i Kalo & \\
\hline Program Site & Loko Ea & Loko Ea/KS & Loko l'a & \\
\hline Program Site & Ma Ka Hana Ka 'lke & Ma Ka Hana Ka 'Ike & 'Āina malo'o/Lo'i kalo & \\
\hline Program Site & Mâlama Hale'iwa Lơi & Fitzsimmon 'Ohana & Loi kalo & \\
\hline Program Site & MA'O Organic Farms/Farm2Fork & MA'O Organic Farms & 'Āina malo'o & $\begin{array}{l}\text { K. Maunakea-Forth \& Abbott (2015); Enos } \\
\text { (2015) }\end{array}$ \\
\hline Program Site & Māla Kalu'ulu & Mãla Kalu'ulu & 'Āina malo'o & Lincoln et al. (2018) \\
\hline Program Site & Maluaka & Maluaka & 'Āina malo'o & Lincoln et al. (2018) \\
\hline Program Site & Mămaki Farm & Kamehameha Schools & 'Āina malo'o & \\
\hline Program Site & Noho'ana Farm & Noho'ana Farm & Lo'i kalo/Māla'ai & \\
\hline Program Site & Nā Mea Kūpono & Nã Mea Kûpono & Loi kalo & \\
\hline Program Site & Paepae o He'eia & Paepae o Heeia/KS & Loko i'a & Moehlenkamp et al. (2018) \\
\hline Program Site & Papahana Kuaola & Papahana Kuaola/KS & Lo'i kalo & Nahale-a, Rueles, Kon (2015) \\
\hline Program Site & Ulu Mau Puanui & Ulu Mau Puanui & 'Āina malo'o & Lincoln et al. (2018) \\
\hline Program Site & Ulupō & Hika'alani & Heiau/Loi kalo & \\
\hline Program Site & Waianu Farm & Uncle Charlie \& Paul Reppun & Lo'i kalo/'Äina malo'o & \\
\hline Program Site & Waikalua Loko l'a & Pacific American Foundation & Loko l'a & \\
\hline Program Site & Waipã Foundation & Waipă Foundation & Ahupua'a & Blaich (2003); Vaughan (2018) \\
\hline Program Sites at Schools & Ka Papa Lo'i 'o Kãnewai & Ho'okahe Wai Ho'oulu 'Āina/UH Mãnoa & Loi kalo & Maunakea (2016) \\
\hline Program Sites at Schools & Ka Papa Lo'i Project - 'Aihualama & Hâlau Kũ Mana & Loi kalo & Goodyear-Ka'ōpua (2013) \\
\hline Program Sites at Schools & Ka iwakīloumoku Hawailian Cultural Center & KS - Kapālama & 'Āina malo'o & \\
\hline Program Sites at Schools & Kahuola & BYU-Hawai'i & Lo'i Kalo/"Āina malo'o & \\
\hline Program Sites at Schools & Ke Kula Kaiapuni 'o Ãnuenue & Ke Kula Kaiapuni 'o Ånuenue & Lo'i Kalo & \\
\hline Program Sites at Schools & $\begin{array}{l}\text { Māla'ai: The Culinary Garden of Waimea } \\
\text { Middle School }\end{array}$ & Măla'ai & 'Āina malo'o & \\
\hline Program Sites at Schools & Waipi'o Valley with Uncle Nālei Kahakalau & Kanu O Kã 'Āina PCS & Lo'i kalo & Nãone (2008) \\
\hline Program Sites at Schools & WCC Nursing Pathways Garden & Windward Community College & ‘Āina malo'o/Lā'au lapa'au & \\
\hline
\end{tabular}

